\title{
IMPLEMENTASI SISTEM MERIT PADA APARATUR SIPIL NEGARA
} DI INDONESIA

\section{THE IMPLEMENTATION OF MERIT-BASED SYSTEM ON STATE CIVIL APPARATUS IN INDONESIA}

\author{
Anggita Chariah, Ariski S, Agus Nugroho, dan Adi Suhariyanto \\ Universitas Gadjah Mada. Bulaksumur, Caturtunggal, Kec. Depok, Kabupaten \\ Sleman, Daerah Istimewa Yogyakarta 55281, Indonesia \\ Email: anggitachairiah@mail.ugm.ac.id
}

Naskah diterima: 23 Mei 2020; revisi terakhir: 20 November 2020; disetujui: 17 Desember 2020

How to Cite: Chariah, Anggita., Ariski S., Nugroho, Agus., dan Suhariyanto, Adi. (2020). Implementasi Sistem Merit pada Aparatur Sipil Negara di Indonesia. Jurnal Borneo Administrator, 16 (3), 383-400. https://doi.org/10.24258/jba.v16i3.704

\begin{abstract}
High performance and competency are the demands that nowadays must be owned by State Civil Apparatus known as ASN. Those demands can be achieved if the human resources' screening process is carried out lawfully and correctly by procedures. This article aims to examine the management of State Civil Apparatus in Indonesia using the merit system theory based on several phenomena. The data were analyzed using qualitative techniques, namely a descriptive phenomenological analysis. The discussion focuses on the development and particular phenomenon of the merit system in Indonesia's current situation, starting from the beginning of the selection and recruitment process, the placement of ASN, and implementing a merit system based on competency. Research result showed that the implementation of the merit system in Indonesia has not yet been thoroughly carried out based on the right procedures. More importantly, to become a dynamic governance also requires firm awareness of all stakeholders' responsibility, which is the primary key to executing a merit system in Indonesia. However, the improvement of supervision also needs to be done, especially by KASN, to optimize the merit system's implementation.
\end{abstract}

Keywords: Merit System, State Civil Apparatus (ASN), Performance Appraisal, Human Resource Management

\begin{abstract}
Abstrak
Kinerja dan kompetensi tinggi merupakan salah satu tuntutan yang harus dimiliki ASN saat ini. Hal ini bisa diwujudkan jika proses penyaringan sumber daya manusia yang unggul dilakukan dengan jujur dan benar sesuai dengan prosedur. Artikel ini bertujuan untuk mengkaji manajemen Aparatur Sipil Negara di Indonesia menggunakan teori sistem merit berdasarkan beberapa
\end{abstract}


fenomena yang ada. Data dianalisis menggunakan teknik analisis data kualitatif, yakni descriptive phenomenological analysis. Pada pembahasan fokus penelitian, dipaparkan pelaksanaan serta beberapa fenomena penerapan sistem merit pada ASN di Indonesia saat ini dari awal proses seleksi dan rekrutmen, penempatan ASN hingga penerapan sistem merit berdasarkan kompetensi. Hasil penelitian menemukan bahwa penerapan sistem merit di Indonesia masih belum sepenuhnya dilakukan sesuai prosedur. Kunci sukses lainnya, agar menjadi dynamic governance diperlukan kesadaran penuh dari semua pemangku kepentingan dalam menerapkan sistem merit di Indonesia. Namun, peningkatan pengawasan juga perlu dilakukan terutama oleh KASN agar implementasi sistem merit dapat optimal.

Kata Kunci: Sistem Merit, Aparatur Sipil Negara (ASN), Penilaian Kinerja, Manajemen Sumber Daya Manusia

\section{A. PENDAHULUAN}

Pencapaian good governance membutuhkan reformasi administrasi publik dalam peningkatan kinerja aparat pelayanan publik yang sesuai kompetensi (Dwiyanto, 2015; Sudarman, Hasim, \& Maswati, $2020: 2-3$; Wahjusaputri \& Fitriani, 2018 : 28-33). Tuntutan ini tentunya membutuhkan sumber daya manusia yang berkualitas (Darmi, 2017:3107). Pencapaian good governance yang profesional, kinerja berkualitas, transparan, akuntabel serta mampu menegakkan etika dan moral dalam melayani publik tentu tidak terlepas dari manajemen sumber daya manusia yang baik (Destianingrum, Hananto, \& Sa'adah, 2017:13). Sumber daya manusia adalah salah satu faktor pokok yang strategis untuk meningkatkan kemampuan bersaing (competitive) dan bertahan (defensive) bagi institusi sesuai perkembangan arus globalisasi. Salah satu cara agar sebuah institusi dapat survive dalam kompetensi global, yaitu perlu suatu landasan guna mencapai keunggulan bersaing yaitu pengelolaan sumber daya manusia yang memadai agar menghasilkan sumber daya manusia yang kompeten (Pfeffer, 1994 : 1-281).

Manajemen Aparatur Sipil Negara menjadi salah satu fokus pembangunan pemerintah pada tahun 2020. Melalui Kementerian Perencanaan Pembangunan Nasional/Bappenas telah disusun Rancangan Teknokratis Rencana Pembangunan Jangka Menengah Nasional (RTRPJMN) 2020 - 2024 yang merupakan Rencana Pembangunan Jangka Menengah Nasional (RPJMN) tahap ke-4 dari Rencana Pembangunan Jangka Panjang Nasional (RPJPN) 2005 - 2025. Rencana Pembangunan Jangka Menengah Nasional 2020 - 2024 diarahkan untuk pengembangan sumber daya manusia yang lebih baik, melalui sektor publik maupun pemberdayaan dari sektor nonpublik untuk mencapai SDM yang berdaya saing global.

Selanjutnya, pemerintah juga telah menyusun agenda Prioritas Pembangunan Bidang. Khusus di bidang aparatur, Kementerian PPN/Bappenas telah menyusun tiga prioritas pembangunan, yaitu (1) peningkatan akuntabilitas kinerja, pengawasan dan reformasi birokrasi; (2) peningkatan inovasi dan kualitas pelayanan publik; dan (3) penguatan implementasi manajemen ASN berbasis merit. Pembangunan manajemen ASN untuk mewujudkan birokrasi berkelas dunia yang profesional, berintegritas dan netral sejatinya telah dimulai sejak kebijakan sistem merit dalam manajemen ASN dilaksanakan. UndangUndang Nomor 5 Tahun 2014 Tentang Aparatur Sipil Negara (ASN) adalah dasar hukum yang dengan tegas mengamanatkan bahwa instansi pemerintah harus menerapkan sistem merit dalam manajemen ASN. Sistem merit didefinisikan sebagai kebijakan dan manajemen 
ASN yang berdasarkan kualifikasi, kompetensi, dan kinerja, yang diberlakukan secara adil dan wajar tanpa diskriminasi. Definisi tersebut tercantum dalam Undang-Undang No. 5 Tahun 2014 Tentang Aparatur Sipil Negara (ASN) dimana dalam sistem merit yang paling diutamakan adalah kualifikasi yang mencakup dalam seleksi dan rekruitmen pegawai, kompentensi dan penempatan dari ASN itu sendiri.

Namun, pada kenyataannya, penerapan sistem merit di Indonesia masih menghadapi berbagai tantangan yang harus dibenahi oleh pemerintah, khususnya dalam menerapkan strategi manajemen sumber daya manusia. Hasil penelitian Komisi Aparatur Sipil Negara pada tahun 2018 pada Gambar 1 menemukan peta penerapan sistem merit manajemen ASN di beberapa kementerian rata-rata sudah tergolong baik, tetapi masih terdapat lima kementerian yang termasuk dalam kategori II, yakni kurang (KASN 2018a : 14). Kondisi demikian tentu membutuhkan alternatif solusi berupa penggunaan metode sistem merit yang efektif mulai dari perekrutan ASN hingga pengawasan.

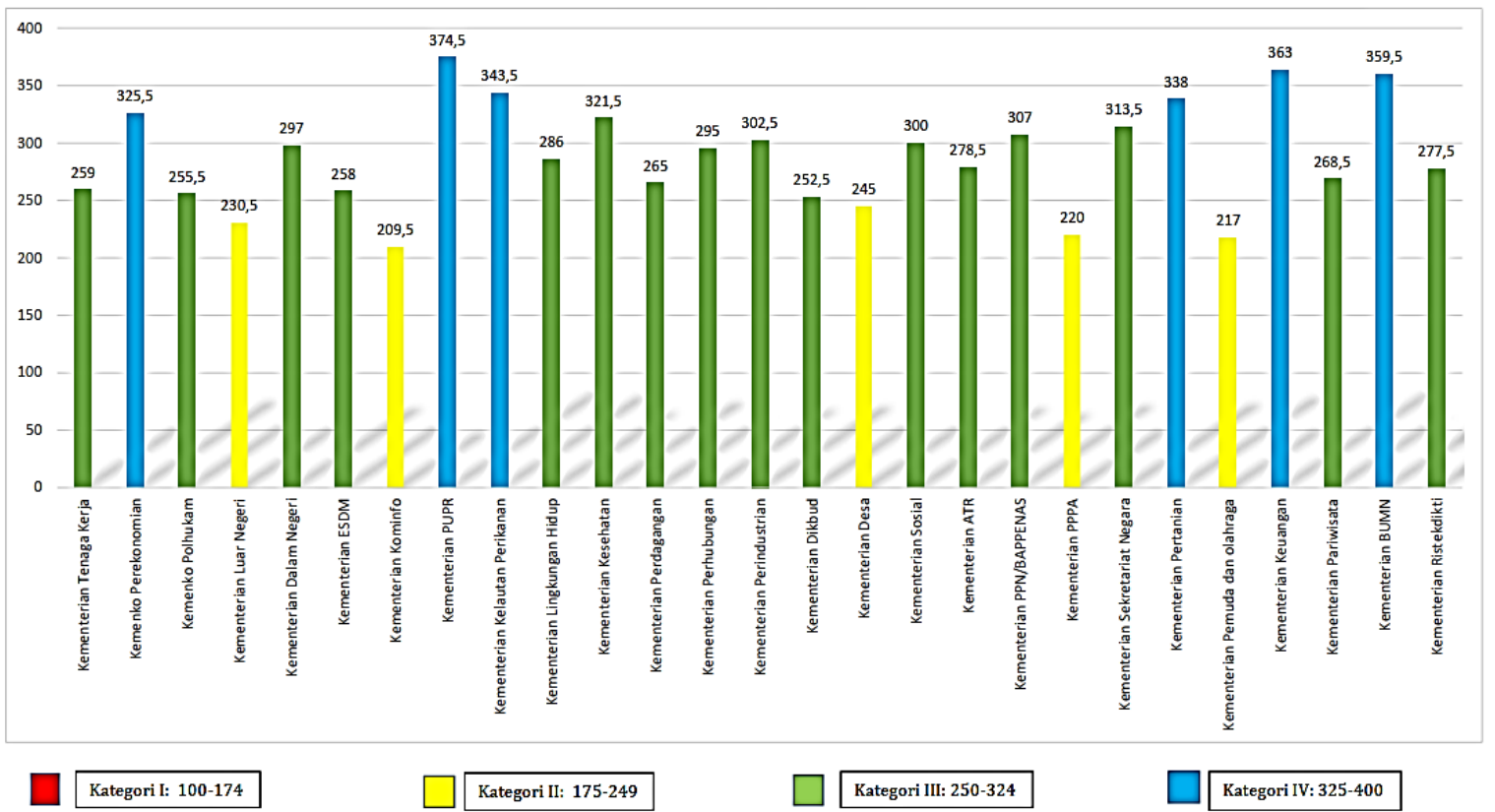

Gambar 1.

Peta Penerapan Sistem Merit Menajamen Aparatur Sipil Negara (ASN) di Beberapa Kementerian Tahun 2018 (Sumber: KASN, 2018a:17)

Berbagai praktik yang mencerminkan ketidaksiapan penerapan sistem merit dalam hal buruknya mutu pelayanan dan kinerja aparat negara (Daryanto, 2007:1; Mulyawan \& Mariana, 2016:2). Sistem pembayaran gaji yang tidak memadai sering kali membuat pegawai bekerja tidak optimal dan dapat memicu terjadinya praktik korupsi (Katharina, 2018:2). Sementara itu, indikator yang menjadi tolok ukur buruknya kinerja aparat pelayanan publik di Indonesia, antara lain pelayanan yang cenderung birokratis dan berteletele, membutuhkan biaya yang tinggi, adanya pungutan liar, perilaku anggota yang kurang baik terhadap masyarakat, pelayanan yang diskriminatif, lebih mendahulukan kepentingan pribadi, pelayanan yang lamban, dan sebagainya (MENPANRB, 2015:74). Susanto (2017: 67-68) mengatakan terdapat beberapa hal yang harus diperbaiki untuk mencapai manajemen sumber daya manusia yang baik, yakni mencakup perbaikan integrasi dan perencanaan, 
keterlibatan pimpinan dalam proses rencana strategis organisasi, pembuatan tujuan dan strategi organisasi yang jelas serta kebijakan dan praktik sumber daya manusia yang selaras.

Bertolak dari urgensi permasalahan tentang pentingnya penerapan sistem merit pada manajemen ASN di Indonesia, rumusan penelitian ini dibatasi mengenai (1) proses rekrutmen ASN secara umum di Indonesia, (2) penempatan ASN (3) implementasi penerapan sistem merit berbasis kompetensi sebagai suatu alternatif solusi untuk meningkatkan kinerja ASN yang mendukung good governance. Dilihat dari berbagai permasalahan di atas, sangat penting bagi instansi pemerintah untuk membenahi manajemen sumber daya manusia dengan menggunakan kebijakan sistem merit dimulai dari tahapan awal perekrutan, penempatan aparat negara yang sesuai dengan kualifikasi, kompetensi, dan kinerja. Berdasarkan latar belakang permasalahan diatas, artikel ini bertujuan untuk mengkaji tentang sistem merit dalam manajemen Aparatur Sipil Negara di Indonesia.

\section{B. METODE PENELITIAN}

Metode penelitian yang digunakan untuk membahas rumusan masalah yang ditetapkan ialah deskriptif dengan pendekatan kualitatif yang bersifat induktif (Creswell, 2014:38). Penelitian kualitatif memberikan kontribusi yang berharga ketika dilaksanakan kegiatan identifikasi masalah dan pembahasan terhadap berbagai sumber data yang menjadi objek kajian (Sugiyono, 2019:271-272). Penelitian kualitatif juga sesuai untuk mencapai tujuan dalam menghasilkan kajian tentang rekomendasi kebijakan sistem merit dalam manajemen ASN. Pendekatan penelitian yang digunakan dalam penelitian ini adalah Descriptive Phenomenological Analysis (DPA). Pendekatan fenomenologi merupakan pendekatan penelitian yang dimulai oleh Husserl (1859-1938) kemudian dikembangkan kembali oleh Heidegger untuk memahami atau mempelajari pengalaman hidup seorang manusia. Hingga pada akhirnya penelitian ini berevolusi menjadi sebuah metode penelitian kualitatif yang banyak digunakan dalam dekade terakhir abad ke dua puluh (Christensen, Welch, \& Barr, 2017:117). Uraian yang dijelaskan dalam pembahasan ini akan mengarah pada berbagai fenomena rekrutmen ataupun penetapan aparatur negara agar mendapatkan gambaran implementasi sistem merit berbasis kompetensi di Indonesia.

Pengumpulan data sekunder yang berupa literatur relevan dengan tema penelitian dilakukan dengan menggunakan teknik content analysis. Beberapa tahapan yang dilalui untuk memperoleh data sekunder mencakup penelusuran literatur melalui internet browsing (collecting data), data diseleksi dan kategorisasi data, lalu analisis materi dan terakhir yakni uji literatur dan entry data dan sajian data dalam pembahasan. Analisis data dilakukan dengan memproses berbagai informasi agar dapat menggambarkan keadaan sistem merit di Indonesia. Literatur bersumber dari hasil penelitian terdahulu, konsep dan teori yang telah terbit dalam jurnal ilmiah dan beberapa buku hasil pemikiran para ahli.

\section{KERANGKA TEORI}

Sistem merit di Indonesia telah diatur dalam Undang-Undang ASN pasal 2 (dua) butir 22, dengan pengertian sistem merit adalah "Kebijakan dan manajemen ASN yang berdasarkan pada kualifikasi, kompetensi dan kinerja secara adil wajar dengan tanpa membedakan latar belakang politik, ras, warna kulit, agama, asal usul, jenis kelamin, status pernikahan, umur ataupun kondisi kecatatan”. Sistem merit bertujuan untuk menciptakan kompetensi sumber daya manusia yang profesional dan produktif sesuai manajemen ASN, yang menata seleksi dan rekrutmen pegawai, pengembangan pegawai dan kesempatan setiap pegawai dalam promosi jabatan. Target ini sesuai dengan sistem merit berbasis kompetensi. 


\section{Konsep Manajemen Sumber Daya Manusia Berbasis Merit System}

Sumber daya manusia berperan penting dalam segala aspek kehidupan, mulai dari level mikro, yaitu keluarga, sampai masyarakat. Sementara, manajemen sumber daya manusia merupakan sistem formal di dalam suatu organisasi guna memastikan potensi sumber daya yang tersedia secara efektif dan efisien dalam upaya mencapai tujuan organisasi (Boon, Den Hartog, \& Lepak, 2019:12). Manajemen sumber daya manusia dibangun untuk memotivasi dan mengembangkan staf agar mereka dapat memberikan dukungan terbaik dalam pencapaian misi organisasi (Bakator et al., 2019:3-13). Nilai strategis sistem merit telah dijelaskan secara teoritis oleh Woodard (2000:20-29) yaitu tentang seleksi kepegawaian, penempatan, promosi, dan kompensasi harus didasarkan pada sistem prestasi dan kompetensi dan faktor lain, seperti nilai-nilai individu untuk meningkatkan manajemen sumber daya manusia. Penerapan sistem merit yang tidak dipengaruhi perekrutan menurut gender, usia, suku dan faktor nonmerit lainnya pada manajemen sumber daya manusia dapat menarik pegawai yang tepat serta dapat mengembangkan potensi pegawai untuk meningkatkan kapabilitasnya (KASN, 2018b:5). Realisasi terap sistem merit dan kompetensi dipercaya menunjang pertumbuhan ekonomi dan mereduksi korupsi, kolusi, nepotisme ataupun favoritism (Dahlström, Lapuente, \& Teorell, 2012:659; Vveinhardt \& Sroka, 2020:3). Prestasi kerja pada konsep sistem merit menurut Wungu (dalam Daryanto, 2007:3) merupakan pusat dari sistem merit (lihat Gambar 2), artinya untuk meningkatkan kinerja pegawai itu sendiri melalui kompetensi dan potensi yang dimilikinya. Jika prestasi yang didapatkan pegawai tersebut baik, maka pegawai (sumber daya manusia) akan mendapatkan penghargaan atau reward berupa kenaikan gaji atau kenaikan karier jabatan. Sebaliknya, jika prestasi pegawai (sumber daya manusia) buruk maka akan mendapatkan punishment berupa penurunan penghasilan ataupun karier dan jabatan. Reward dan Punishment dinilai dapat mempengaruhi sikap-sikap serta perilaku seorang pegawai dalam bekerja (Putra \& Damayanti, 2020:312).

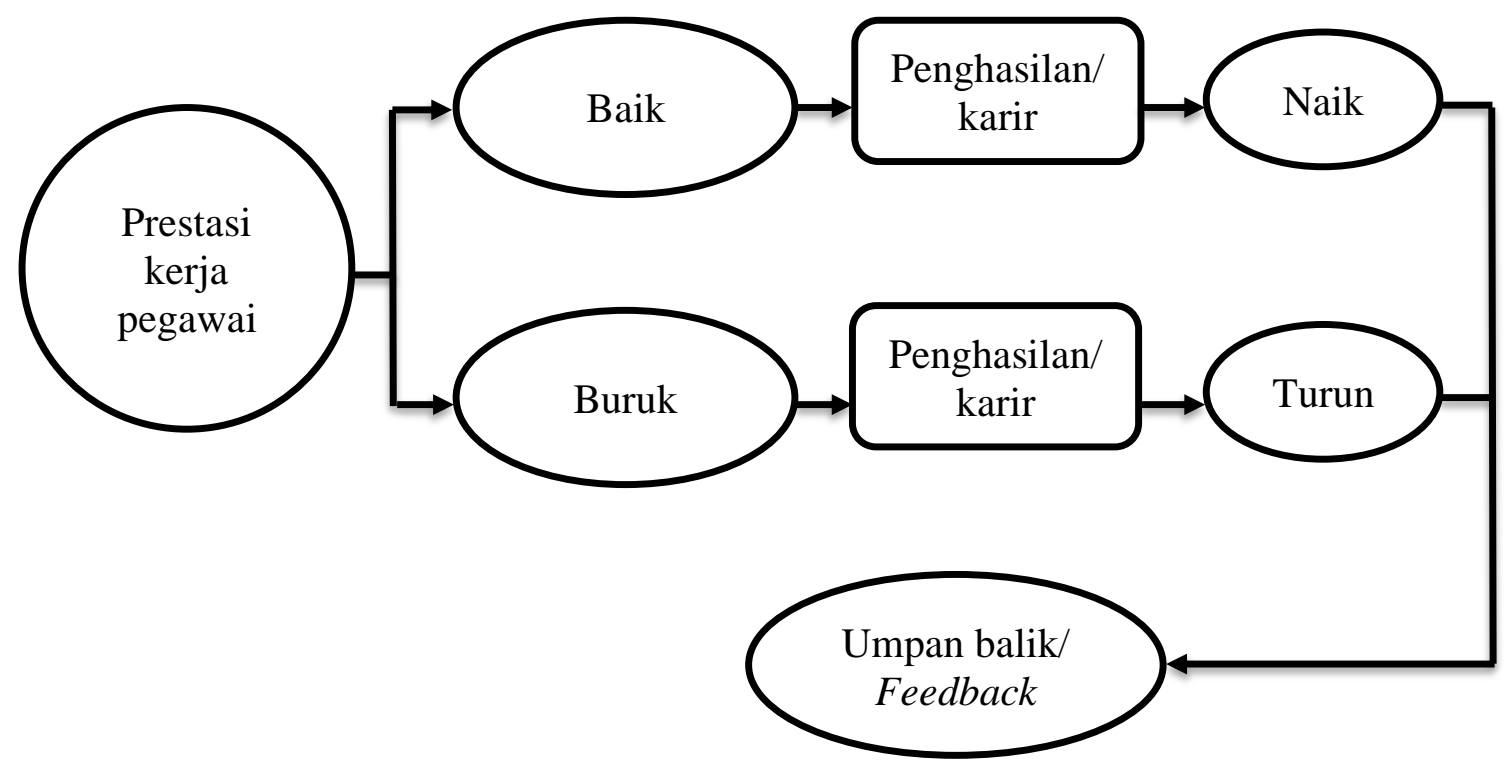

Gambar 2.

Konsep Sistem Merit (Sumber: Wungu, dalam Daryanto, 2007:3) 
Dalam penerapan sistem merit juga tidak terlepas dari kinerja dan kompetensi pegawai. Sejumlah penelitian menunjukkan terdapat pengaruh antara manajemen berbasis sistem merit dan kinerja organisasi publik untuk membuat perubahan ke arah positif (Gabris et al., 1985:311-327; Kim \& Holzer, 2016:19-20; Murphy, 2019:23-24; Sartika et al., 2016:63). Komara (2019:75) menyebutkan bahwa salah satu faktor yang dapat meningkatkan kinerja dan profesionalisme pegawai ASN dalam melayani publik adalah dengan membuat iklim kerja yang sehat dan dinamis. Budaya organisasi atau budaya kerja yang positif dapat dilakukan dengan membangun komunikasi yang respektif, peningkatan kedisiplinan pegawai, membuat aturan organisasi yang jelas (Mustafid, 2017:1-14). Penerapan reward and punishment bagi pegawai juga dapat meningkatkan motivasi ASN dalam melayani publik (Putra \& Damayanti, 2020:312; Verbruggen \& McLaren, 2018:356) dalam penelitiannya menemukan bila terlalu banyak penekanan pada evaluasi kinerja dapat menurunkan motivasi karyawan, hal demikian dapat diselesaikan dengan melakukan pengembangan dan pembelajaran pegawai agar mendorong penerimaan terhadap penilaian kinerja dan meningkatkan kepuasan pegawai. Sementara itu, kompetensi adalah suatu kemampuan, keahlian maupun perilaku dalam melaksanakan tanggung jawab pekerjaan yang dilandasi oleh pengetahuan dan keterampilan yang dimiliki ASN sesuai dengan standar yang diperlukan (Sartika et al., 2016:26-27).

\section{HASIL DAN PEMBAHASAN}

\section{Sistem Seleksi dan Rekrutmen CPNS}

Pegawai ASN memiliki fungsi dan tanggung jawab untuk melayani masyarakat secara profesional, jujur, adil, tidak diskriminatif, menjaga kenetralan dalam menyelenggarakan kebijakan publik (Prasojo, 2014:24). Sementara itu, Pegawai Negeri Sipil (PNS) merupakan salah satu elemen penting dari ASN yang membutuhkan aplikasi sistem evaluasi kinerja (prestasi kerja) melalui sistem merit. Hal ini menjadi urgent, mengingat jumlah pegawai ASN yang masuk melalui jalur CPNS tergolong tinggi. Mempertimbangkan eksistensi PNS yang dibutuhkan untuk melayani publik, maka pengkajian secara mendalam diperlukan mengenai sistem seleksi dan rekrutmen CPNS.

Kinerja birokrasi yang buruk pada pegawai negeri sipil sering kali diidentifikasi sebagai penjelasan dari menurunnya kepercayaan masyarakat pada pemerintah (Houston et al., 2016:1204). Seiring berjalannya waktu, gerakan reformasi manajemen sumber daya manusia terjadi dengan kemunculan desentralisasi. Burns et al (dalam Ishii, Rohitarachoon, \& Hossain, 2013:250) menjelaskan bahwa di negara maju, desentralisasi juga kerap diperkenalkan sebagai respons terhadap ketidakpuasan publik pada birokrasi pemerintah yang sering kali tidak responsif dan efisien dalam melayani publik. Kualitas dan kompetensi aparatur negara yang rendah dapat menghambat kegiatan pemerintah dan membuat mereka tidak mampu bersaing dengan sektor swasta (Rakhmawanto, Rusli, \& Sintaningrum, 2019:31).

Merespons tantangan reformasi tersebut, pemerintah Indonesia dalam menyikapi the decline of citizen-trust mencoba menerapkan kebijakan desentralisasi dan sistem merit dalam proses seleksi dan rekrutmen calon pegawai sipil negara. Merekrut individu yang kompeten dalam melayani publik tidak hanya tergantung pada sistem manajemen SDM. Akan tetapi penting juga mempertimbangkan konteks politik, sosial, dan ekonomi. Selain dapat menyaring sumber daya manusia yang kompeten, sistem merit dinilai dapat mengurangi terjadinya korupsi dan mencegah nepotisme dalam birokrasi (Dahlström et al., 2012, pp. 665-666; Vveinhardt \& Sroka, 2020:3). 
Meraih minat masyarakat Indonesia untuk turut serta menjadi ASN adalah hal yang dapat dikatakan mudah. Terbukti pada tahun 2019, Badan Kepegawaian Negara (2020) melalui Sistem Seleksi Calon Aparatur Sipil Negara (SSCASN) mencatat sejumlah 4.197.218 calon peserta telah melakukan pendaftaran, dan sebanyak 3.364.897 telah lolos verifikasi administrasi dan terdapat sebanyak 154.029 formasi, yang terdiri dari instansi pusat sebanyak 37.584 formasi dan instansi daerah sebanyak 116.445 formasi. Jumlah tersebut meningkat dari tahun-tahun sebelumnya. Sebaliknya, menarik peserta yang memiliki kompetensi unggul dalam bidangnya, dan siap berkomitmen menjadi pelayan publik menjadi tantangan tersendiri bagi birokrasi di Indonesia. Seberapapun inovatifnya sebuah badan publik dalam menarik pelamar, keberhasilan instansi dalam merekrut pegawai dengan integritas yang tinggi akan sulit didapat kecuali jika kondisi fundamentalnya sudah kuat (Lavinga \& Hays, 2004:239).

Dasar hukum perekrutan dan seleksi pegawai pemerintahan di Indonesia adalah Undang-Undang No.5 Tahun 2014 Tentang ASN (Pasal 56-67) dan PP No. 11 Tahun 2017 Tentang Manajemen PNS (Pasal 4-44). Sementara itu, terdapat peraturan yang cukup berbeda dari tahun sebelumnya untuk mengatur standar kompetensi calon PNS yaitu Peraturan Menteri Pendayagunaan Aparatur Negara dan Reformasi Birokrasi Republik Indonesia Nomor 24 Tahun 2019 Tentang Nilai Ambang Batas Seleksi Kompetensi Dasar (SKD) CPNS Tahun 2019. Peraturan lainnya yaitu Peraturan Badan Kepegawaian Negara Nomor 50 Tahun 2019 Tentang Prosedur penyelenggaraan seleksi dengan metote Computer Assisted Test (CAT).

Badan Kepegawaian Negara (2019:1-36) menyatakan bahwa metode Computer Assisted Test harus digunakan dalam proses dan seleksi rekrutmen Calon Pegawai Negeri Sipil (PNS), seleksi Calon Pegawai Pemerintah dengan Perjanjian Kerja (PPPK), seleksi masuk sekolah kedinasan, seleksi pengembangan karier, dan seleksi selain Aparatur Sipil Negara (ASN) untuk menunjang penyaringan pegawai secara objektif, transparan, akuntabel, dan bebas dari korupsi, kolusi dan nepotisme. Computer Assisted Test merupakan salah satu sistem seleksi yang menggunakan alat bantu komputer untuk memperoleh lulusan yang memenuhi standar minimal kompetensi yang telah dibuat pada peraturan nilai ambang batas. Proses Seleksi Kompetensi Dasar (SKD) menunjukkan bagian dari rangkaian kegiatan seleksi yang dimaksudkan untuk menggali pengetahuan, keterampilan, dan perilaku peserta ujian. Cakupan penilaian pada saat seleksi terdiri dari Tes Wawasan Kebangsaan (TWK), Tes Intelegensi Umum (TIU), dan Tes Karakteristik Pribadi (TKP). Seleksi Kompetensi Bidang (SKB) merupakan seleksi untuk menilai kesesuaian antara kompetensi bidang yang dimiliki oleh pelamar dengan standar kompetensi bidang yang dipersyaratkan oleh jabatan atau instansi tertentu.

\section{Kondisi Empiris Seleksi dan Rekrutmen CPNS di Indonesia}

Sejak tahun 2013, ujian seleksi Calon Pegawai Negeri Sipil (CPNS) telah memanfaatkan sistem komputer atau Computer Assisted Test (CAT). Perkembangan model seleksi ASN terlihat dalam Tabel 1. Pemerintah menjamin kejujuran dan objektivitas dari sistem CAT sehingga dapat menghindari segala bentuk kecurangan peserta tes. Sistem CAT diharapkan dapat mengukur kemampuan peserta tes secara objektif dalam waktu yang relatif singkat. Beberapa keuntungan penggunaan sistem ini antara lain yaitu lebih kompetitif, adil, dan mudah dimengerti oleh peserta. Setelah seleksi administrasi berlangsung, peserta CPNS yang lolos berhak mengikuti tes tahap berikutnya yakni SKD. Setelah lolos dari tahap ujian SKD peserta dapat mengikuti tes SKB. Adapun tahap akhir yang harus dilalui oleh seorang 
calon PNS yang telah lulus (dapat dilihat pada Gambar 3) mengikuti serangkaian ujian ialah memperoleh Nomor Induk Pegawai (NIP).

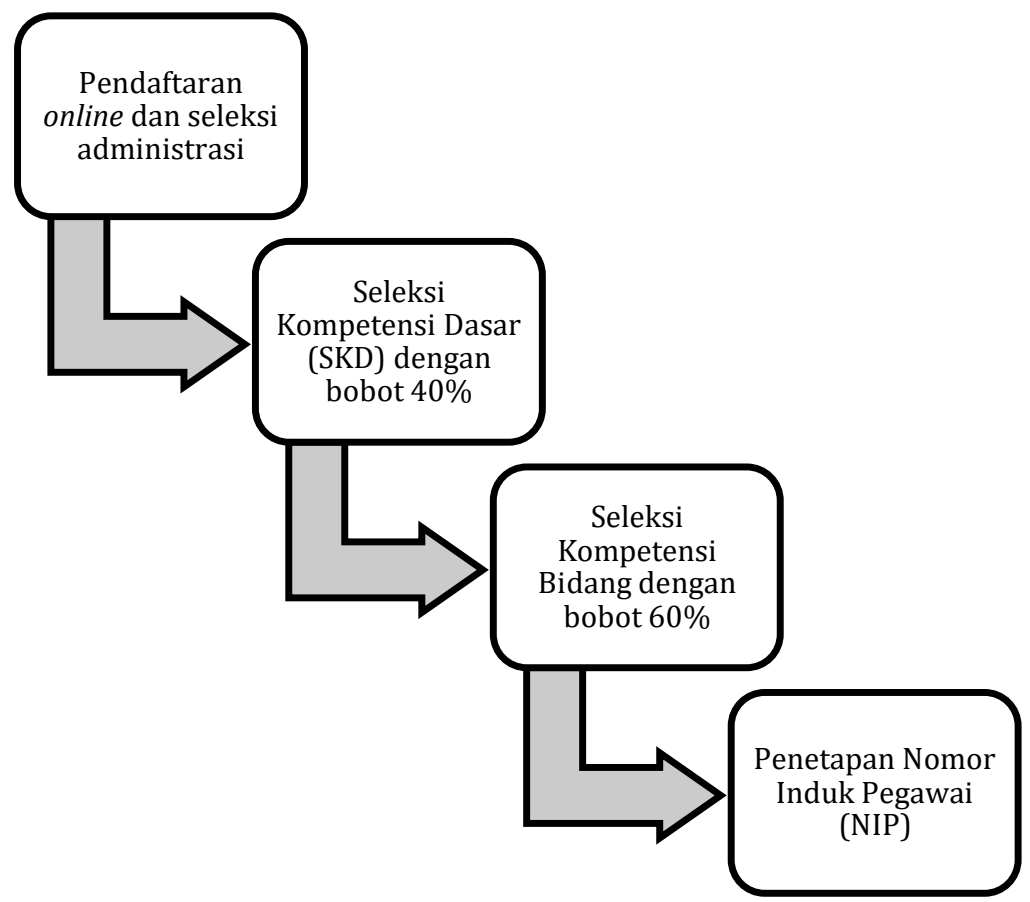

Gambar 3.

Tahapan Seleksi CPNS 2019 (Sumber: BKN, 2020)

Selanjutnya, peserta yang dinyatakan lolos SKD dan melewati ambang batas serta masuk dalam kuota per jabatan akan melanjutkan pada tahap Seleksi Kompetensi Bidang (SKB) yang umumnya berupa tes wawancara, tes bahasa asing, tes fisik, tes potensi akademik, dan psikotes lanjutan dengan syarat setiap instansi harus memberikan minimal dua bentuk tes. Materi SKB untuk jabatan fungsional disusun oleh instansi pembina jabatan fungsional yang nantinya akan diintegrasikan ke dalam bank soal CAT BKN. Sebagai contoh, soal tes SKB jabatan fungsional Analis Kebijakan akan disusun oleh Lembaga Administrasi Negara (LAN).

Penerapan sistem merit pada seleksi dan rekrutmen CPNS di Indonesia masih memiliki beberapa permasalahan. Setyowati (2016) melakukan riset terkait seleksi CPNS di tahun 2010. Setyowati (2016:92-93) dalam penelitiannya menemukan terdapat tiga faktor yang menghambat penerapan merit system dalam rekrutmen dan seleksi karyawan. Pertama adalah faktor administratif, kedua politis dan budaya yang bisa menunjukkan indikasi korupsi dalam proses rekrutmen dan yang ketiga adalah hambatan teknis yang terkait dengan kemampuan sumberdaya personel yang terbatas dalam melaksanakan tanggung jawab.

Dilansir dari Kedeputian BKN Bidang Wasdal, pada tahap awal perencanaan seleksi CPNS 2019 masih ditemui beberapa jenis maladministrasi seperti pelanggaran pasal 22 ayat 3 PP 11/2017, yaitu adanya perbedaan syarat minimal IPK bagi putra-putri daerah dan non putra-putri daerah yang bersangkutan. Hal demikian terjadi pada 77 instansi daerah dan 4 instansi pusat. Pelanggaran Pasal 22 PP 11/ 2017 di 22 instansi daerah juga ditemukan, yaitu membatasi domisili pelamar dalam wilayah kabupaten/provinsi tertentu. 
Tabel 1

Model Seleksi Calon Pegawai Negeri Sipil (CPNS) tahun 2010-2019

\begin{tabular}{clc}
\hline No. & \multicolumn{1}{c}{ Model Seleksi } & Tahun \\
\hline 1 & $\begin{array}{l}\text { Kerja sama daerah dengan Perguruan Tinggi } \\
\text { (PT). Sudah ada yang online tetapi mayoritas } \\
\text { masih menggunakan sistem konvensional/ } \\
\text { manual. }\end{array}$ & 2010 \\
2 & $\begin{array}{l}\text { Terpusat, menggunakan CAT, tetapi belum } \\
\text { terintegrasi. }\end{array}$ & 2013 \\
3 & $\begin{array}{l}\text { Terpusat, menggunakan CAT, tetapi belum } \\
\text { terintegrasi. }\end{array}$ & 2014 \\
4 & $\begin{array}{l}\text { Terpusat, menggunakan CAT, terintegrasi, } \\
\text { terbuka dan online }\end{array}$ & 2017 \\
5 & $\begin{array}{l}\text { Terpusat (seleksi nasional), terintegrasi, } \\
\text { terbuka, online, Single Entry System } \\
\text { (SSCN), CAT. }\end{array}$ \\
6 & $\begin{array}{l}\text { Terpusat (seleksi nasional), terintegrasi, terbuka, } \\
\text { online, Single Entry System (Sistem Seleksi } \\
\text { Calon Aparatur Sipil Negara/SSCASN), CAT, } \\
\text { penyesuaian Passing Grade }\end{array}$ & 2019 \\
\hline
\end{tabular}

Sumber: Analisis Peneliti

Berbagai permasalahan lain terkait seleksi dan rekrutmen CPNS dari tahun sebelumnya sampai saat ini cenderung masih memiliki pattern permasalahan yang sama. Sering kali prinsip "the right man on the right place" masih diabaikan. Metode seleksi yang digunakan saat ini terkesan menggeneralisasi seluruh kemampuan peserta ujian. Keterbatasan anggaran khususnya bagi instansi daerah juga masih sering ditemukan. Saviar dan Prasojo (2014:14-15) menemukan adanya instansi yang tidak menyelenggarakan Seleksi Kompetensi Bidang karena keterbatasan waktu dan dana. Kejadian seperti itu akan membuat instansi memiliki risiko tidak mendapatkan pelamar yang tepat karena kompetensi bidang ditiadakan. Pelanggaran lain terdapat pada sejumlah instansi yang melakukan seleksi terbuka tetapi tidak sepenuhnya memenuhi prosedur yang berlaku, bahkan beberapa instansi masih merekrut Jabatan Pimpinan Tinggi Pratama tetapi tidak melalui seleksi terbuka (Dwiputrianti, 2018:78).

Strategi pemerintah dalam menyikapi berbagai permasalahan terkait rekrutmen dan seleksi pegawai harus benar-benar berlandaskan pada penilaian kompetensi dari pelamar. Beberapa hal yang perlu dilakukan oleh pemerintah dalam mewujudkan good governance yakni penambahan alokasi anggaran urusan kepegawaian, perubahan mindset terkait pentingnya proses rekrutmen dan seleksi SDM yang unggul, pemerataan teknologi internet yang mengikuti perkembangan zaman, metode seleksi harus sesuai dengan kompetensi jabatan tidak menggeneralisasi. Tidak hanya bagi ASN dan CPNS yang akan masuk, bahkan sistem rekrutmen yang menerapkan tes kompetensi dasar dan bidang perlu diadakan pada rekrutmen Pegawai Tidak Tetap (PTT) agar mendapatkan SDM yang kompeten (Rakhmawanto, 2013:3).

\section{Penempatan Aparatur Sipil Negara}

Penempatan merupakan bagian terpenting yang harus dijalankan setelah tahap seleksi. Penempatan jabatan bisa juga berupa pemberian tugas pada posisi tertentu, atau pengisian 
jabatan yang kosong, atau bisa juga dalam bentuk jabatan pada pegawai yang baru. Penempatan jabatan tersebut dapat diartikan sebagai suatu aktivitas sebagai babak lanjutan dari proses penyaringan pegawai yang mencakup penempatan kandidat pegawai yang lulus seleksi pada jabatan atau pekerjaan tertentu melalui delegasi (Hasibuan, 2010, p. 163). Pengertian lain dari penempatan ASN dapat ditafsirkan sebagai salah satu fungsi terpenting dalam manajemen sumber daya manusia melalui pemberian tugas ataupun jabatan kepada seseorang pada posisi tertentu. Penempatan ASN tergantung pada fungsi dan kesesuaian kompetensi diri dengan jabatan ataupun tugas yang membutuhkan untuk mencapai tujuan organisasi.

Dapat dinyatakan bahwa penempatan merupakan salah satu unsur penting yang harus dijalankan setelah proses seleksi selesai dan harus melalui perhitungan yang matang supaya dapat mendukung tercapainya tujuan organisasi dengan menempatkan pegawai baru pada suatu posisi tertentu. Hasibuan (2010:63) berpendapat bahwa dalam menempatkan pegawai yang telah lolos seleksi harus berdasarkan kompetensi yang dibutuhkan dalam jabatan tertentu, atau lebih dikenal dengan asas "the right man in the right place and the right man behind the right job." Pendapat tersebut dapat diartikan bahwa penempatan pegawai tidak bisa serta merta sembarang dilakukan, tetapi harus melalui pertimbangan tertentu atau yang lebih sering disebut analisis jabatan sesuai kompetensi supaya tidak menempatkan pegawai yang tidak berkompetensi pada suatu pekerjaan.

Terdapat enam prinsip dasar dalam penempatan pegawai menurut Adewale, (dalam Babalola Oluwayemi et al., 2018:43-44) yakni pegawai harus selalu ditempatkan berdasarkan persyaratan yang ada, kedua, suatu pekerjaan harus ditawarkan kepada seseorang yang telah memiliki kualifikasi yang tepat, ketiga, pegawai harus mempunyai pemahaman kuat mengenai apa yang menjadi tanggung jawabnya, tidak luput bahwa loyalitas, kerja sama antar karyawan, beban tugas harus terus dikembangkan, kelima, penempatan jabatan harus dipersiapkan jauh-jauh hari, dan yang terakhir penempatan pegawai dapat digunakan sebagai percobaan untuk mengukur seberapa layak pegawai menempati sebuah jabatan.

Prosedur proses penempatan pegawai bila dimulai dengan analisis pekerjaan dan setiap penempatan yang dilakukan sesuai dengan prosedur akan membuat instansi atau organisasi mendapatkan pegawai yang terbaik yang dapat meningkatkan kinerja organisasi (Babalola Oluwayemi et al., 2018:43). Terdapat beberapa faktor yang memengaruhi dalam penempatan jabatan seorang pegawai, menurut Hasibuan (dalam Epriani, 2016:30) faktor-faktor tersebut meliputi pendidikan terakhir, kondisi kesehatan, baik jasmani maupun rohani, usia calon pegawai, serta berbagai pengalaman bekerja. Kesalahan penempatan pegawai dalam bidang tertentu dapat menyebabkan unit kerja akan merasakan akibatnya.

Penerapan konsep yang sudah dijelaskan pada paparan sebelumnya dalam penempatan pegawai khususnya aparatur sipil negara diharapkan dapat ditempatkan sesuai job description dan job specification sehingga efisiensi dan efektivitas organisasi tercapai. Oleh karena itu, penulis ingin memberikan beberapa contoh kasus yang bisa menjadikan potret penempatan pegawai di Indonesia. Kasus yang akan penulis ambil di antaranya dari berbagai instansi baik pusat maupun daerah berdasarkan data yang ada.

Terdapat beberapa kasus yang ditemukan. Pada Dinas Kependudukan dan Pencatatan Sipil Kabupaten Tana Toraja, dimana data diambil dari penelitian Epriani (2016:105) yang mengungkapkan bahwa penempatan Pegawai Negeri Sipil pada Dinas Kependudukan dan Pencatatan Sipil Kabupaten Tana Toraja bisa dikatakan baik, tetapi kurang efektif karena beberapa hal belum terlalu diperhatikan. Aspek tersebut yaitu keterampilan dan kepribadian. Pada aspek keterampilan pegawai di instansi ini belum mumpuni dan masih perlu 
peningkatan di bidang pengolahan data dan pelayanan secara online (Epriani, 2016:6). Sementara pada aspek kepribadian berhubungan dengan minat kerja pegawai yang masih rendah sehingga hal ini berakibat pada efektifitas pekerjaan yang dilakukan (Epriani, 2016:98). Hasil penelitian tersebut memberikan gambaran bahwa di instansi daerah, masalah penempatan pegawai belum menjadi fokus utama untuk efektivitas tujuan organisasi.

Kasus berikutnya, yaitu ada pada Pemerintah Kota Depok yang beritanya dikutip dari Media Indonesia (Rajagukguk:2020) bahwa banyak sekali laporan yang masuk kepada Ombudsman RI, informasi ini disampaikan oleh pejabat keasistenan dalam tim tujuh, yaitu Ahmad Sobirin. Beliau mengungkapkan bahwa laporan yang masuk mengenai penempatan pegawai birokrat di Kota Depok yang tidak berdasarkan kompetensi, seperti seorang doktor dalam bidang persampahan dari Institut Pertanian Bogor ditempatkan pada posisi jabatan kepala bidang kependudukan di Dinas Kependudukan dan Pencatatan Sipil.

Selain itu, ada juga ASN yang memiliki gelar insinyur dalam bidang sumber daya air menduduki jabatan sebagai kabid kebakaran Dinas Damkar dan Penyelamatan. Masih banyak lagi contoh kasus lainnya mengenai penempatan yang tidak sesuai bukan hanya di Kota Depok, tetapi hampir terjadi di seluruh Indonesia (Rajagukguk:2020). Penelitian dari Wildatul Aluf (2019:107) yang berlokasi di Kantor Kementerian Agama Kota Surabaya Seksi Pendidikan Madrasah menemukan bahwa penempatan pegawai di Seksi Pendidikan Madrasah belum sempurna karena tidak sesuai dengan prestasi akademis. Namun, untuk penempatan pegawai berdasarkan pengalaman yang dimiliki, di Seksi Pendidikan Madrasah sudah hampir menyesuaikan untuk mengisi sebuah jabatan. Selain itu, pegawai pada Seksi Pendidikan Madrasah telah memiliki kesehatan fisik dan mental yang dapat memperbaiki kinerja pegawai.

Masalah penempatan jabatan juga terjadi di tingkat Kementerian RI salah satunya Kementerian Agama. Komisi Pemberantasan Korupsi telah berhasil menguak dugaan suap pada berbagai jabatan di lingkungan Kementerian Agama (Wiwoho:2019). Kasus ini mulai terungkap sejak lembaga ini berhasil menangkap praktik korupsi jabatan. Nama-nama yang dikantongi KPK di antaranya adalah ketua Umum PPP M Romahurmuzy alias Romi, Kepala Kantor Wilayah Kemenag Jawa Timur Haris Hasanuddin dan Kepala Kantor Kemenag Kabupaten Gresik M.M Wirahadi. KPK kemudian menetapkan Romi yang juga anggota Komisi XI DPR, Muafaq dan Haris sebagai tersangka jual beli jabatan di Kemenag.

Praktik jual beli jabatan semacam ini memberikan gambaran bahwa penempatan jabatan di Indonesia masih kacau. Praktik maladministrasi masih kerap ditemukan. Dalam hal ini tentunya faktor-faktor dalam penempatan jabatan seperti kemampuan, kompetensi, dan keterampilan sudah tidak menjadi dasar pertimbangan dalam penempatan. Kiat-kiat yang dapat dilakukan untuk mengantisipasi penyelewengan tersebut diperlukan adanya perbaikan dalam penyatuan peraturan terkait mekanisme pengangkatan pejabat tinggi yang mengacu pada sistem merit serta pembatasan kewenangan kepala instansi dalam mengangkat pejabat atau pegawai (Wijaya et al., 2019:204).

\section{Penerapan Sistem Merit Berdasarkan Kompetensi}

Pada bagian ini akan membahas lebih lanjut mengenai penerapan merit system berdasarkan kompetensi. Apabila mengacu pada visi Indonesia 2045 yakni mengembangkan perekonomian berkelanjutan yang dilakukan secara gencar (KASN, 2019:3). Adanya visi tersebut menyebabkan pemerintah mulai menyadari agar dapat mencapainya sangat diperlukan ASN yang mempunyai kompetensi yang baik ketika menduduki suatu jabatan tertentu. Kompetensi adalah gambaran tentang perilaku sedangkan kompeten (kecakapan) adalah gambaran dari hasil suatu pekerjaan (Palan, 2007:6). 
Dalam upaya meningkatkan efektivitas merit system yang sedang dilaksanakan, pemerintah Indonesia telah mengambil langkah menyederhanakan birokrasi yang ada di semua lembaga dan kementerian yang ada di Indonesia. Berdasarkan mandat presiden, penyederhanan tersebut dilakukan dengan merampingkan jabatan eselon menjadi dua level saja yakni eselon I dan II serta mengganti jabatan eselon III (administrator) dan eselon IV (pengawas) dengan jabatan fungsional yang lebih menekankan pada menghargai kompetensi dan keahlian yang harus dilaksanakan. Mandat prsesiden tersebut telah tertuang dalam Surat Edaran Nomor 384, 390 dan 391 Tahun 2019 Tentang Langkah Strategis dan Konkret Penyederhanaan Birokrasi yang ditujukan kepada semua menteri kabinet Indonesia maju, gubernur, wali kota dan bupati serta semua instansi pemerintahan baik pusat maupaun daerah (Asmara, 2020:1-2).

Salah satu upaya penting dalam menyeleksi ASN yang berkompeten adalah dengan adanya pengembangan kompetensi. Pengembangan kompetensi dapat diperoleh melalui program pengembangan berupa pendidikan dan pelatihan (diklat), pertukaran pegawai dan praktik kerja (KASN, 2019:20-35). Selain itu, kompetensi bisa didapatkan melalui berbagai cara seperti pengalaman hidup dan aktivitas di tempat kerja dan program pengembangan (Wu, 2013:262). Adanya penyederhanaan birokrasi tersebut sangat mendukung dalam pelaksanaan sistem merit saat ini, dengan mengutamakan kompetensi dan keahlian yang dimiliki oleh masing-masing ASN. Penyedehanaan birokrasi tersebut juga dapat membantu lembaga pengawasan ASN, yakni Komisi Aparatur Sipil Negara (KASN) dalam menjalankan tugasnya sebagai pengawas sistem merit yang ada di pemerintahan Indonesia.

Hal tersebut dapat sebagai pemacu untuk para ASN agar dapat meningkatkan kompetensi dan keahliannya agar dapat menduduki jabatan fungsional tersebut, melalui pendidikan dan pelatihan yang sesuai dengan jabatan fungsional yang akan diduduki. Selain itu, langkah yang dapat dilakukan adalah penilaian yang ketat pada akhir proses pendidikan dan pelatihan jabatan fungsional tersebut dengan tujuan ketika para ASN sedang mengikuti pendidikan dan pelatihan benar-benar belajar dan memahami materi yang telah diberikan oleh pemateri dalam pelatihan dan pendidikan tersebut. Aparat negara yang telah menyelesaikan pendidikan dan pelatihan dapat menjadi ASN yang memiliki kompentensi dan keahlian yang lebih baik dibandingkan sebelum mengikuti pelatihan dan pendidikan serta dapat menjalankan tugasnya sebagai pejabat fungsional sesuai dengan aturan yang ada.

Di samping itu, pada praktiknya pengembangan kompetensi masih sering diabaikan oleh beberapa instansi pemerintah dan masih kurang teratur. Hal tersebut dapat terlihat dari beberapa kementerian, lembaga dan pemerintahan daerah belum mempunyai daftar yang memadai dalam hal perencanaan kompetensi, misalnya jika diadakan pelatihan yang mengikuti hanya pegawai yang berminat. Begitu pula dengan kurangnya minat pegawai untuk melanjutkan pendidikan (Sambali, 2015:158). Hal ini terlihat sangat tidak sistematis karena seharusnya semua ASN mengikuti pelatihan yang diadakan oleh instansi pemerintah tempatnya bekerja, secara bergantian antar sesama ASN, bukan hanya ASN yang berminat saja.

Undang-Undang Nomor 5 Tahun 2014 Tentang Aparatur Sipil Negara telah membuka ruang bagi ASN dalam pengembangan kompetensi, dimana setiap ASN berhak mendapatkan pengembangan diri selama 20 jam dalam setahun serta UU tersebut mengharuskan instansi pemerintah untuk membuat daftar perencanaan pengembangan ASN dalam setiap tahunnya. Namun, masih ada beberapa instansi pemerintah yang tidak menjalankan tugas tersebut, sehingga mengakibatkan terjadinya berbagai permasalahan manajemen ASN dalam penerapan sistem merit. Permasalahan demikian terjadi ketika akan dilakukan penempatan ASN terutama dalam pengisian Jabatan Pimpinan Tinggi (JPT) berupa Panitia JPT yang 
berkompeten, kredibel dan nonpolitik menjadi sangat terbatas, jumlah assesor dan assessment center yang terakreditasi yang juga terbatas, serta pengisian JPT yang belum berdasarkan kualifikasi, kompetensi, dan kebutuhan organisasi (Dwiputrianti, 2018:78).

Permasalahan tersebut mengakibatkan banyak posisi di instansi pemerintah diisi oleh ASN yang tidak berkompeten dan takut bersaing secara sehat dengan ASN lainya. Oleh karena itu, adanya sistem merit ini diharapkan dapat menciptakan ASN yang memiliki kompetensi ketika menduduki suatu jabatan tertentu serta ASN yang lebih peduli terhadap kebutuhan masyarakat dengan memberikan pelayanan yang maksimal. Selain itu, pentingnya sinergitas antara badan kepegawaian dan lembaga diklat pada semua tingkatan karena kedua lembaga tersebut yang paling mengetahui kebutuhan diklat bagi ASN (LAN:2016). Agar dapat mencapai tujuan tata kelola pemerintahan yang baik, diperlukan beberapa hal yang harus dilakukan oleh pemerintah dalam aspek kompetensi dalam sistem merit pada ASN di Indonesia. Dalam mengatasi permasalahan tersebut, Lembaga Administrasi Negara (LAN) telah mengeluarkan acuan mengenai pengembangan kompetensi dalam Peraturan LAN Nomor 10 Tahun 2018 tentang Pengembangan Kompetensi ASN.

Adanya peraturan tersebut diharapkan dapat menjadi acuan dalam pelaksanaan program peningkatan kompetensi dasar. Beberapa kementerian di Indonesia sudah mulai mengembangkan kompetensi dengan membuat rencana diklat secara sistematis, contohnya adalah Kementerian Keuangan. Adanya pedoman mengenai kompetensi tersebut seharusnya menjadikan semua instansi pemerintah mulai mengikuti membuat daftar rencana diklat rutin setiap tahunnya di instansi masing-masing secara sistematis. Hal yang dapat dilakukan selanjutnya adalah mewajibkan semua ASN untuk mengikuti diklat setiap tahunnya secara bergantian antara sesama pegawai minimal satu kali dalam satu tahun, jika tidak mengikuti diklat tersebut selama dua kali berturut-turut, ASN harus mendapatkan punishment berupa pemindahan tugas atau non-job. Kehadiran diklat rutin dapat meningkatkan kompetensi individu ASN. Apabila ASN semakin berkompeten, ASN dapat ditempatkan pada posisi apa saja yang sesuai dengan kompetensinya dan dapat pula mempermudah kenaikan jabatan.

Langkah berikutnya yang dapat dilakukan oleh instansi pemerintah, baik pusat dan daerah serta lembaga diklat adalah dengan mengadopsi sistematika diklat yang dilaksanakan pada sektor private yang cocok diterapkan pada sektor pemerintah agar dapat meningkatkan kompetensi ASN untuk mendukung manajemen ASN dan sistem merit di Indonesia. Kemudian merancang kurikulum diklat yang sesuai lembaga, kementerian atau pemerintah daerah yang akan mengikuti diklat sesuai dengan kebutuhan masing-masing setiap instansi pemerintah tersebut yang harus ditekankan dalam pelaksanaan diklat, misalnya untuk Kementerian Pekerjaan Umum maka kurikulum pengetahuan yang harus ditekankan adalah mengenai manajemen konstruksi karena kementerian tersebut mengurusi pembangunan infrastruktur, sedangkan pada pemerintahan daerah yang termasuk dalam daerah rawan bencana, kurikulum pengetahuan yang harus ditekankan pada ASN pada saat mengikuti diklat adalah mengenai kebijakan mitigasi bencana dan pascabencana agar para ASN di daerah tersebut mempunyai pedoman ketika terjadi bencana yang datang secara tiba-tiba, serta lebih responsif dan tidak lamban dalam mengambil keputusan.

Selanjutnya, salah satu aspek yang perlu diperhatikan ketika akan diadakan suatu diklat adalah fasilitas ketika mengikuti diklat agar sesama ASN tidak saling lempar ketika diminta untuk mengikuti diklat seperti fasilitas akomodasi dan transport dengan kualitas yang baik, dapat menjadi daya tarik para ASN untuk mengikuti diklat yang diadakan instansi pemerintah tempatnya bekerja. Segala upaya tersebut dapat berjalan dengan baik apabila terus dilakukan oleh intansi terkait secara berkala misalnya dalam satu tahun dua kali agar 
tidak terjadi penyelewengan yang dilakukan para ASN dalam program pengembangan kompetensi ASN melalui diklat. Para lembaga terkait yang akan menyelenggarakan diklat harus terus memberikan kesadaran kepada para ASN betapa pentingnya diklat peningkatan kompetensi. Selain bermanfaat untuk individu ASN, dapat pula berupa naiknya posisi jabatan ASN serta meningkatnya tunjangan kinerja dan jabatan yang akan didapatkan. Manfaat lain bagi instansi tempat para ASN bekerja yaitu apabila telah memiliki ASN yang kompeten dan berkualitas tentu akan meningkatkan kemajuan instansi mereka. Pegawai ASN akan dapat membuat program-program atau kebijakan yang berkualitas dan bermanfaat bagi semua aspek.

Berdasarkan semua uraian di atas terdapat satu pihak yang sangat berperan penting dalam pengembangan kompetensi ASN tersebut yakni atasan langsung yang paling paham mengenai kompetensi yang dimiliki bawahannya dengan cara mengamati kinerja dan tugastugas yang diselesaikan (PPID LAN:2018). Oleh karena itu, atasan sangat berperan dalam pengembangan kompetensi ini sebagai pihak yang paling mengetahui mengenai bawahannya. Tindakan yang dapat dilakukan oleh seorang atasan adalah dengan memberikan motivasi dan semangat kepada seluruh pegawai agar tidak menolak untuk mengikuti program diklat yang akan diadakan.

Dengan adanya motivasi yang membangun dapat menyadarkan para pegawai betapa pentingnya program diklat untuk peningkatan kompetensi ASN. Perbaikan tata kelola pemerintahan juga perlu bertindak dinamis. Budaya birokrasi perlu disentuh untuk lebih cepat tanggap, responsif, dan efisien sesuai dengan kebutuhan masyarakat Indonesia saat ini. Dynamic governance dapat diterapkan agar kebijakan yang dikeluarkan oleh pembuat kebijakan dapat lebih adaptif melalui tiga kunci sukses dalam menentukan pemimpin yakni diperlukan pemimpin yang dapat berpikir kedepan dan antisipatif (think ahead), pemimpin yang dapat mengkaji ulang secara hati-hati hasil pemikirannya (think again), dan pemimpin yang mampu berpikir secara lateral, horizontal, dan mengambil pelajaran dari berbagai perspektif (think across) (Neo \& Chen, 2007: 467-469). Terakhir, di masa industry 4.0 tentu peningkatan kompetensi melalui metode e-learning berupa penggunaan teknologi komunikasi dan informasi juga sangat dibutuhkan dalam pembelajaran para ASN agar mendapat akses pembelajaran di mana pun dan kapan saja dengan menggunakan jaringan internet (Daniati \& Marliani, 2019:102; Rahman, Amarullah, \& Hidayah, 2020,:103). Penggunaan model campuran atau blended learning yang diawali dengan metode e-learning dapat meningkatkan proses belajar mandiri dan pengetahuan ASN sebelum masuk ke proses belajar klasikal atau tatap muka secara langsung, penggabungan kedua model tersebut diharapkan agar proses pembelajaran ASN lebih terintegrasi dan optimal (Idris, 2018:62).

\section{E. PENUTUP}

Sistem merit yang diterapkan di Indonesia masih belum sepenuhnya berlangsung optimal sesuai dengan peraturan yang berlaku. Komitmen dan kerja sama antara ASN dengan semua instansi dalam lingkungan kementerian, lembaga, pemerintah pusat maupun daerah dalam upaya mewujudkan keberhasilan sistem merit yang akuntabel dan objektif. Sangat penting kerja sama antara ASN dan semua kementerian, lembaga, pemerintahan pusat dan daerah untuk mewujudkan keberhasilan sistem merit di Indonesia.

Berdasarkan hasil penelitian ini, terdapat beberapa hal yang direkomendasikan yakni urgensi dari pengawasan oleh Komisi Aparatur Sipil Negara (KASN) terhadap implementasi sistem merit perlu ditingkatkan dan didukung kontrol independen dari elemen masyarakat lainnya. Hal ini dimaksudkan untuk menghindari sedini mungkin berbagai bentuk penyimpangan dalam seleksi pegawai aparatur negara. Kesadaran tentang sistem merit 
sebagai kunci keberhasilan dalam penerimaan pegawai ASN perlu ditingkatkan untuk mencapai hasil yang optimal.

Peningkatan kompetensi ASN memerlukan komitmen bersama dari unit organisasi untuk mendukung suksesnya pendalaman pengetahuan melalui inovasi digital (blended learning) yang juga penting untuk diimplementasikan, baik dalam lingkup pemerintahan pusat maupun daerah. Sejalan dengan itu, perlunya perbaikan internal pemerintah di era industri 4.0 saat ini perlu menerapkan strategi jangka panjang mengenai tata kelola pemerintahan yang dinamis (dynamic governance), yaitu kemampuan birokrasi untuk lebih adaptif dan progresif perlu ditingkatkan melalui tiga cara yakni think ahead, think again, serta think across untuk membangun sistem merit di tata kelola pemerintahan yang baik.

\section{DAFTAR PUSTAKA}

Aluf, W. (2019). Penempatan Aparatur Sipil Negara (ASN) Melalui Kualifikasi Jabatan Di Seksi Pendidikan Madrasah Kantor Kementerian Agama Kota Surabaya (Universitas Islam Negeri Sunan Ampel Surabaya). https://doi.org/10.1109/MTAS.2004.1371634

Asmara, C. G. (2020). Kabar Terbaru Penghapusan PNS Eselon III dan IV. Retrieved August 7,2020, from $\quad$ CNBC Indonesia website: https://www.cnbcindonesia.com/news/20200221115010-4-139527/kabar-terbarupenghapusan-pns-eselon-iii-dan-iv-simak/2

Babalola Oluwayemi, O., Patience, E., Femi Christopher, O., \& Sola J., L. (2018). The Implications Of Employee's Placement On National Development: A Case Of Nigeria. World Journal of Business and Management, 4(1), 39-52. https://doi.org/10.5296/wjbm.v4i1.12982

Badan Kepegawaian Negara. Peraturan Kepala Badan Kepegawaian Negara No. 50 Tahun 2019 tentang Prosedur Penyelenggaraan Seleksi dengan Metode Computer Assisted Test Badan Kepegawaian Negara. , (2019).

Badan Kepegawaian Negara. (2020). Pemerintah Tidak Batalkan Pelaksanaan SKB CPNS Formasi 2019. Jakarta Timur: Badan Kepegawaian Negara.

Bakator, M., Petrović, N., Borić, S., \& Đalić, N. (2019). Impact Of Human Resource Management On Business Performance: A Review Of Literature. Journal of Engineering Management and Competitiveness, 9(1), 3-13. https://doi.org/10.5937/jemc1901003b

Boon, C., Den Hartog, D. N., \& Lepak, D. P. (2019). A Systematic Review Of Human Resource Management Systems And Their Measurement. SAGE Journals: Journal of Management, 45(6), 1-40. https://doi.org/10.1177/0149206318818718

Christensen, M., Welch, A., \& Barr, J. (2017). Husserlian Descriptive Phenomenology: A Review Of Intentionality, Reduction And The Natural Attitude. Journal of Nursing Education and Practice, 7(8), 113. https://doi.org/10.5430/jnep.v7n8p113

Creswell, J. W. (2014). Research Design (Qualitative, Quantitative, and Mixed Methods Approaches). Sage Publications.

Dahlström, C., Lapuente, V., \& Teorell, J. (2012). The Merit Of Meritocratization: Politics, Bureaucracy, And The Institutional Deterrents Of Corruption. Political Research Quarterly, 65(3), 656-668. https://doi.org/10.1177/1065912911408109

Daniati, S. I., \& Marliani, R. S. (2019). Pelatihan Berbasis Kompetensi pada Pelatihan Fungsional Kemetrologian. Prosiding Seminar Stiami, 6(1), 101-112. Retrieved from https://doi.org/10.1016/j.snb.2019.127013

Darmi, T. (2017). The Role Of Human Resources (HR) State Civil Apparatus (Asn) To Improve Performance Of New Autonomous Region (DOB) in Seluma Regency of 
Bengkulu Province. International Conference on Global Education V, (April 2017), 3107-3116. Padang: Universitas Ekasakti.

Daryanto, A. (2007). Merit System Dalam Manajemen Pegawai Negeri Sipil. Jurnal Kebijakan Dan Manajemen PNS, 1(2), 1-13. https://doi.org/10.1084/jem.50.6.713

Destianingrum, B., Hananto, U. D., \& Sa'adah, N. (2017). Profesionalisme Birokrat Dalam Implementasi Good Governance Menuju Terwujudnya Negara Bebas Korupsi Kolusi Nepotisme (KKN) di Kota Semarang. Diponegoro Law Journal, 6(2), 1-17.

Dwiputrianti, S. (2018). Challenges With Implementation Of The Merit System In The Open Recruitment Of Government High Positions: The Case In Indonesia. Asian Association for Public Administration Annual Conference (AAPA), 191, 70-80. https://doi.org/10.2991/assehr.k.200316.059

Dwiyanto, A. (2015). Lima Kriteria ASN. Retrieved June 12, 2020, from Kementerian Pendayagunaan Aparatur Negara website: https://www.menpan.go.id/site/beritaterkini/lima-kriteria-asn-kelas-dunia

Epriani, I. S. (2016). Analisis Penempatan Pegawai Negeri Sipil Pada Dinas Kependudukan Dan Pencatatan Sipil Kabupaten Tana Toraja. Universitas Hasanuddin.

Gabris, G. T., Mitchell, K., Public, S., Review, P., Winter, N., \& Taylor, P. (1985). Merit Based Performance Appraisal And Productivity: Do Employees Perceive The Connection? Public Productivity Review, 9(4), 311-327. https://doi.org/10.2307/3379942

Hasibuan, M. S. P. (2010). Manajemen Sumber Daya Manusia (Revisi). Jakarta: Bumi Aksara.

Houston, D. J., Aitalieva, N. R., Morelock, A. L., \& Shults, C. A. (2016). Citizen Trust In Civil Servants: A Cross-National Examination. International Journal of Public Administration, 39(14), 1203-1214. https://doi.org/10.1080/01900692.2016.1156696

Idris, H. (2018). Pembelajaran Model Blended Learning. Jurnal Ilmiah Iqra', 5(1), 61-73. https://doi.org/10.30984/jii.v5i1.562

Ishii, R., Rohitarachoon, P., \& Hossain, F. (2013). HRM Reform In Decentralised Local Government: Empirical Perspectives On Recruitment And Selection In The Philippines and Thailand. Asian Journal of Political Science, 21(3), 249-267. https://doi.org/10.1080/02185377.2013.864514

KASN. (2018a). Pemetaan Penerapan Sistem Merit dalam Manajemen Aparatur Sipil Negara (ASN). Jakarta.

KASN. (2018b). Pengawasan Penegakan Kode Etik dan Kode Perilaku Pegawai Aparatur Sipil Negara. Jakarta.

KASN. (2019). Penilaian Penerapan Sistem Merit dalam Manajemen ASN di Instansi Pemerintah Tahun 2019. Jakarta.

Katharina, R. (2018). Reformasi Manajemen Aparatur Sipil Negara: Evaluasi Peran Pejabat Pembina Kepegawaian Dan Komisi Aparatur Sipil Negara. Jurnal Administrasi Publik, 13(5), 1-16. https://doi.org/https://doi.org/10.2096/sp.v13i2.24864

Kim, T., \& Holzer, M. (2016). Public Employees And Performance Appraisal: A Study Of Antecedents To Employees' Perception Of The Process. Review of Public Personnel Administration, 36(1), 31-56. https://doi.org/10.1177/0734371X14549673

Komara, E. (2019). Kompetensi Profesional Pegawai ASN (Aparatur Sipil Negara) Di Indonesia. Kompetensi Profesional Pegawai ASN (Aparatur Sipil Negara) Di Indonesia, 4(1), 73-84. https://doi.org/10.17509/mimbardik.v4i1.16971

LAN. (2016, May 24). Kompetensi ASN Masih Hadapi Sejumlah Permasalahan. Retrieved May 16, 2020, from Lembaga Administrasi Negara website: http://lan.go.id/id/2016- 
01-05-13-26-55/berita/kompetensi-asn-masih-hadapi-sejumlah-permasalahan

Lavinga, R. J., \& Hays, S. W. (2004). Recruitment And Selection Of Public Workers: An International Trends And Practices. Public Personnel Management, 33(3), 237-254. https://doi.org/10.1177/009102600403300301

MENPANRB. (2015). Birokrasi Bersih, Kompeten Dan Melayani. Jurnal Pendayagunaan Aparatur Negara, $V, 1-190$.

Mulyawan, R., \& Mariana, D. (2016). Profesionalisme Aparat Dan Kapasitas Kelembagaan Dalam Pelayanan Publik Di Provinsi Jawa Barat. Jurnal Ilmu Pemerintahan, 2(2), 119.

Murphy, K. R. (2019). Performance Evaluation Will Not Die, But It Should. Human Resource Management Journal, 30(1), 13-31. https://doi.org/10.1111/17488583.12259

Mustafid, H. (2017). Peningkatan Kinerja Aparatur Sipil Negara Melalui Budaya Organisasi. Jurnal Peningkatan Kinerja Aparatur Sipil Negara, 3(01), 1-14.

Neo, B. S., \& Chen, G. (2007). Dynamic Governance: Embedding Culture, Capabilities And Change In Singapore. In Dynamic Governance: Embedding Culture, Capabilities and Change in Singapore. World Scientific Publishing Co. Pte. Ltd.

Palan, R. (2007). Competency Management: Teknik Mengimplementasikan Manajemen SDM Berbasis Kompetensi Untuk Meningkatkan Daya Saing Organisasi (1st ed.). Jakarta: PPM.

Pfeffer, J. (1994). Competitive Advantage Through People Unleashing The Power Of The Workforce. Boston: Harvard Business School Press.

PPID LAN. (2018). Pengembangan Kompetensi PNS Tanggung Jawab Bersama. Retrieved July 10, 2020, from LAN RI website: http://lan.go.id/id/2016-01-05-13-2655/berita/pengembangan-kompetensi-pns-tanggung-jawab-bersama

Prasojo, E. (2014). Undang-Undang Aparatur Sipil Negara: Membangun Profesionalisme Aparatur Sipil Negara. Jurnal Kebijakan Dan Manajemen PNS, 8(1), 13-31.

Putra, M., \& Damayanti, N. (2020). The Effect Of Reward And Punishment To Performance Of Driver Grabcar In Depok. International Journal of Research and Review, 7(1), 312$\underline{319 .}$

Rahman, M. A., Amarullah, R., \& Hidayah, K. (2020). Evaluasi Penerapan Model Pembelajaran E-Learning Pada Pelatihan Dasar Calon Pegawai Negeri Sipil. Jurnal Borneo Administrator, 16(1), 101-116. https://doi.org/10.24258/jba.v16i1.656

Rajagukguk, K. (2020, March 9). Penempatan Jabatan ASN Harus Didasarkan Sistem Merit. Retrieved May 20, 2020, from Media Indonesia website: https://mediaindonesia.com/read/detail/295399-penempatan-jabatan-asn-harusdidasarkan-sistem-merit

Rakhmawanto, A. (2013). Sistem Rekrutmen Pegawai Berbasis Kompetensi: Analisis Perspektif Pengangkatan PTT Menjadi CPNS. Jurnal Kebijakan Dan Manajemen PNS, 7(2), 1-11.

Rakhmawanto, A., Rusli, B., \& Sintaningrum, S. (2019). Merit System On The Selection Process Of The State Civil Apparatus First Senior Executive Service Officials In The Central Java Provincial Government. Jurnal Bina Praja, (21), 31-41. https://doi.org/10.21787/jbp.11.2019.31-41

Sambali, N. P. (2015). Pengaruh Kompetensi, Budaya Kerja Dan Fasilitas Kerja Terhadap Kinerja Pegawai Perwakilan Badan Kependudukan Dan Keluarga Berencana Nasional Provinsi Sulawesi Tengah. E-Jurnal Katalogis, 3, 157-166.

Sartika, D., Kusumaningrum, M., Aziza, T. N., Luthfie, W., Amrullah, R., Hidayah, K., 
Zakiyah, S. (2016). Pengembangan Kompetensi Aparatur Sipil Negara. In M. Darto \& W. Mariani (Eds.), PKP2A III LAN. Samarinda: PKP2A III LAN Samarinda.

Saviar, R. H., \& Prasojo, E. (2014). Implementasi Merit System Pada Proses Rekrutmen Dan Seleksi Calon Pegawai Negeri Sipil (CPNS ) Tahun 2013 di Kementerian Keuangan dan Kabupaten Kepulauan Meranti. Universitas Indonesia, 1-20.

Setyowati, E. (2016). Merit System In Recruitment And Selection Process Of Civil Servant Candidate In Malang Indonesia (Implementation Of Recruitment And Selection Of

Civil Servant Candidate In 2010). Journal of Administrative Sciences and Policy Studies, 4(1), 83-95. https://doi.org/10.15640/jasps.v4n1a5

Sudarman, F., Hasim, D., \& Maswati, R. (2020). Development Of Technical Competency

Of The State Civil Apparatus At The State Civil Service And Human Resource

Development Agency Of Biak Numfor, Province Of Papua. Kolaborasi : Jurnal Administrasi Publik, 6(1), 1-16. https://doi.org/10.26618/kjap.v6i1.3269

Sugiyono. (2019). Metode Penelitian Kuantitatif, Kualitatif, dan R\&D. Bandung: Alfabeta. Susanto, E. (2017). Change In Paradigm Of Civil Servant Management In Indonesia : From A Traditional Toward A Strategic Approach: Opportunities And Challenges. International Journal of Policy Studies, 8(2), 67-68.

Verbruggen, F., \& McLaren, R. (2018). Effects Of Reward And Punishment On The Interaction Between Going And Stopping In A Selective Stop-Change Task. Psychological Research, 82(2), 353-370. https://doi.org/10.1007/s00426-016-0827-5

Vveinhardt, J., \& Sroka, W. (2020). Nepotism And Favouritism In Polish And Lithuanian Organizations: The Context Of Organisational Microclimate. Sustainability (Switzerland), 12(4), 1-23. https://doi.org/10.3390/su12041425

Wahjusaputri, S., \& Fitriani, S. (2018). Competency Development Of Civil State Apparatus In Term Of Human Resource Management. Advances in Social Science, Education and Humanities Research, (164). https://doi.org/10.2991/icli-17.2018.6

Wijaya, A. F., Kartika, R., Zauhar, S., \& Mardiyono, M. (2019). Perspective Merit System On Placement Regulation Of High Level Official Civil Servants (A Case Study Of Placement Civil Servants In Local Government On Palembang). HOLISTICA - Journal of Business and Public Administration, 10(2), 187-206. https://doi.org/10.2478/hjbpa2019-0025

Wiwoho, B. (2019, June 17). Kasus Jual Beli Jabatan Kemenag, KPK Periksa Calon Rektor UIN. Retrieved May 20, 2020, from CNN Indonesia website: https://www.cnnindonesia.com/nasional/20190617100714-12-403811/kasus-jual-belijabatan-kemenag-kpk-periksa-calon-rektor-uin

Woodard, A. (2000). Merit In Principle, Merit In Practice: An Investigation Into Merit-Based Human Resources Manajement Through The Lens Of Title 5-Exempt Federal Organizations. Retrieved from http://hdl.handle.net/10919/26893

Wu, J. L. (2013). The Study Of Competency-Based Training And Strategies In The Public Sector: Experience From Taiwan. Public Personnel Management, 42(2), 259-271. https://doi.org/10.1177/0091026013487124 